\title{
Pressurized Inhalation, Solution Dosage
}

\section{Form}

National Cancer Institute

\section{Source}

National Cancer Institute. Pressurized Inhalation, Solution Dosage Form. NCI Thesaurus.

Code C149867.

Liquid, usually multidose preparation consisting of a solution intended for inhalation use.

The preparation is presented in a pressurized container usually fitted with a metering dose valve. 